\title{
Laser Surgery versus Radiotherapy for T1-T2N0 Glottic Cancer: A Meta-Analysis
}

\author{
Yan Feng Binquan Wang Shuxin Wen \\ Otorhinolaryngology Head and Neck Surgery, The First Affiliated Hospital of Shanxi Medical University, \\ Taiyuan, China
}

\section{Key Words}

Early glottic cancer $\cdot$ Radiotherapy $\cdot$ Laser surgery •

Meta-analysis

\begin{abstract}
Background: Laser surgery and radiotherapy are commonly used to treat glottic cancer. Objective of Review: To compare outcomes and cost of laser surgery versus radiotherapy for T1-T2N0 glottic cancer. Type of Review: Meta-analysis. Search Strategy: The Cochrane Central Register of Controlled Trials, Ovid MEDLINE ${ }^{\circledR}$ In-Process \& Other NonIndexed Citations, Embase, Web of Science (1990-2010) were searched electronically. Three Chinese journals in otolaryngology were searched manually. Evaluation Method: Retrieved studies were analyzed with Review Manager 5.0 software. Methodological and outcome heterogeneity was analyzed using the $\chi^{2}$ test and the $\mathrm{I}^{2}$ test. Homogeneous and heterogeneous data were analyzed using a fixed random effect model. Results: Eleven studies involving 1,135 patients were included in the analysis. The cure rate did not differ between patients receiving laser surgery versus radiotherapy. Results on voice preservation were inconclusive. The overall cost for laser surgery was lower. Conclusions: The quality of the reported clinical studies is limited.
\end{abstract}

No level I data are available. Nonetheless, our analysis suggests that laser surgery and radiotherapy produce comparable outcomes.

Copyright ๑ 2011 S. Karger AG, Basel

Laryngeal carcinoma is one of the most common head and neck cancers. According to the most recent estimate, 151,000 new cases (approximately 2.0 men and 0.3 women in every 100,000 population) of laryngeal carcinoma were diagnosed worldwide in 2008 [1]. In recent years, however, the incidence rate of laryngeal carcinoma has been increasing in China, apparently due to cigarette smoking, alcohol consumption and industrial pollution [2].

Laryngeal carcinoma may occur in the glottis, supraglottis or subglottis. The prevalence of larynx cancer in the glottis and supraglottis varies with geographic locations; the vast majority of laryngeal carcinoma in China and the United States are glottic cancers. Supraglottic laryngeal carcinoma is relatively rare, and occurs most commonly in Europe and other parts of the world [3]. Glottic cancer is often at its early stage (Tis or T1T2N0M0, based on the TNM staging system) upon diagnosis for the following reasons: (1) lesions in the true vo-

\section{KARGER}

Fax +4161306 1234

E-Mail karger@karger.ch

www.karger.com
(C) 2011 S. Karger AG, Basel

0301-1569/11/0736-0336\$38.00/0

Accessible online at:

www.karger.com/orl
Binquan Wang

Otorhinolaryngology Head and Neck Surgery

The First Affiliated Hospital of Shanxi Medical University

Taiyuan 030001 (China)

Tel. +86 351463 9988, E-Mail wbq_xy@ hotmail.com 
cal cords produce readily noticeable voice changes [3]; (2) the true vocal cords in the glottis region of the larynx are devoid of lymphatic drainage [4].

Early glottic cancer has a relatively good prognosis [5, 6]. The most common treatment options are endoscopic laser surgery and radiotherapy. The goal of the treatment for T1-T2N0M0 glottic cancer is to cure the disease while preserving the vocal cords. Both laser surgery and radiotherapy could achieve high cure rates, but which treatment is superior in voice preservation remains controversial [7-10]. Superior voice quality has been reported after radiotherapy in several studies [9-11] whereas one study reported superior voice quality after laser treatment [7].

There are a few reviews on the use of endoscopic laser surgery and radiotherapy in the treatment of early glottic cancer $[11,12]$, and none of these reviews comprehensively assessed cure rates, voice function-preserving capacity and treatment costs. The present meta-analysis is based on reports published in the past two decades. Specifically, carbon dioxide endoscopic laser surgery was compared to radiotherapy in patients with T1-T2N0M0 glottic cancer. Parameters included overall survival, voice preservation and cost.

\section{Methods}

\section{Search Strategy}

The search was limited to reports published in the English and Chinese languages. Databases were searched using a combination of free text and MESH terms. For the English literature, the following databases were electronically searched: the Cochrane Central Register of Controlled Trials (CENTRAL) (The Cochrane Library Issue 2, 2009), Ovid MEDLINE, Ovid MEDLINE ${ }^{\circledR}$ InProcess \& Other Non-Indexed Citations, Embase and Web of Science. The reference lists of identified articles/reviews were manually searched for additional trials. For the Chinese literature, the Journal of Clinical Otorhinolaryngology Head and Neck Surgery, the Chinese Archives of Otolaryngology-Head and Neck Surgery and the Chinese Journal of Otorhinolaryngology Head and Neck Surgery were manually searched. The time period of the search was from January 1990 to December 2010. The bibliographies listed in the selected articles were cross-examined to identify additional literature. The authors of the original articles were contacted in case of ambiguity with regard to the design and data.

\section{Inclusion Criteria}

All reports included in this review met the following criteria: (1) patients with previously untreated early-stage glottic cancer (i.e. T1-T2N0M0, based on the TNM system); (2) the intervention was carbon dioxide endoscopic laser surgery versus radiotherapy (without salvage procedure). The primary outcome measure was local control rate. The secondary outcome measures included voice handicap index (VHI), quality of life and treatment cost.
Quality Assessment of Included Studies

Retrieved articles were assessed by two independent researchers. The methodological quality of the articles was evaluated by using the ABC rating scale as previously described [13]: level A, high-quality randomized controlled trials; level B, well-designed, nonrandomized clinical trials, and level C, consensus or expert opinions.

\section{Data Collection and Analysis}

For each study, the following data were collected: first author, publication year, study design, number of patients, tumor stage, patient sex, treatment and outcome. The data were analyzed using Review Manager 5.0 software (Nordic Cochrane Centre, Copenhagen, Denmark). We statistically synthesized dates of eligible studies if appropriate. For dichotomous outcomes, relative risk (RR) and 95\% confidence intervals (CIs) were utilized to compare the event rate. For continuous outcomes, data were summarized using weighted mean difference.

Clinical and methodological heterogeneity was assessed using the $\chi^{2}$ test and $\mathrm{I}^{2}$ test. Meta-analyses were performed whenever appropriate. When there was no significant heterogeneity, a fixed-effect model was employed; otherwise, a random-effect model was adopted and the results from each study were individually described without pooling of the data.

\section{Results}

\section{Eligible Studies}

Of the 25 potentially eligible trials, 14 were excluded $[10,14-26]$. The reasons for exclusion are shown in table 1. Eleven studies [27-37] met all inclusion criteria and were included in the final analysis. None of the 11 studies was completely randomized in design; 1 was prospective [35] and all others were retrospective. A total of 1,135 participants were included: 539 were treated with laser surgery and 596 with radiotherapy. Detailed information is presented in table 2 .

\section{Local Control Rate}

Local control rate was reported in 5 studies [31, 32, 34, $35,37]$. Two studies evaluated the 2 -year local control rate $[31,32], 2$ evaluated the 3 -year local control $[34,35]$, and 3 evaluated the 5 -year local control $[32,34,37]$. A metaanalysis of the 5 studies failed to show a significant difference in local control rate at any time (2-year: $\mathrm{RR}=0.55$, 95\% CI: 0.28-1.09; 3-year: RR = 0.84, 95\% CI: 0.48-1.47; 5-year: $\mathrm{RR}=0.90,95 \% \mathrm{CI}$ : 0.59-1.39; fig. 1).

\section{Voice Handicap Index}

The VHI was reported in 6 trials [27-31, 36]. Significant heterogeneity prevented a meta-analysis. No significant difference in total VHI score was found in 3 studies $[28,29,31]$. Two studies reported significantly lower VHI 
Table 1. Characteristics of excluded studies

\begin{tabular}{ll}
\hline Study ID & Reasons for exclusion recorded \\
\hline Phillips et al. [14] & $\begin{array}{l}\text { Early glottic cancer study with Tis, T1, T2. Data on T1-T2N0M0 glottic cancer } \\
\text { patients could not be separated }\end{array}$ \\
\hline Mlynarek et al. [15] & $\begin{array}{l}\text { Patients in surgery group did not undergo carbon dioxide endoscopic laser surgery. } \\
\text { They underwent endoscopic microsurgical resection using a cold-knife technique }\end{array}$ \\
\hline Loughran et al. [16] & $\begin{array}{l}\text { Early glottic cancer study with Tis, T1, and T2. Data on T1-T2N0M0 glottic cancer pa- } \\
\text { tients could not be separated }\end{array}$ \\
\hline Krengli et al. [17] & No outcome of interest reported \\
\hline Jones et al. [18] & $\begin{array}{l}\text { Early laryngeal cancer study with supraglottic, glottic, subglottic. Data on } \\
\text { T1-T2N0M0 glottic cancer patients could not be separated }\end{array}$ \\
\hline Tamura et al. [19] & No outcome of interest reported \\
\hline Wedman et al. [20] & No outcome of interest reported \\
\hline Spector et al. [21] & Not all participants in surgery group received carbon dioxide endoscopic laser surgery \\
\hline Grégoire et al. [22] & For laser surgery, cost included postoperative radiotherapy applied in 30\% of patients \\
\hline Rosier et al. [10] & This study includes 11 cases who had a previous history of malignant disease \\
\hline Foote et al. [23] & $\begin{array}{l}\text { Early glottic cancer study with Tis, T1 and T2. Data on T1-T2N0M0 glottic cancer pa- } \\
\text { tients could not be separated }\end{array}$ \\
\hline Rydell et al. [24] & No outcome of interest reported \\
\hline McGuirt et al. [25] & No outcome of interest reported \\
\hline Chen et al. [26] & Open surgery was included \\
\hline
\end{tabular}

scores $(\mathrm{p}<0.05)$ in patients receiving radiotherapy $[27$, 30]. The remaining study claimed significantly higher VHI scores $(p<0.05)$ in patients receiving radiotherapy [36]. Data with regard to emotional and functional changes were also conflicting. Better emotional scores were achieved by patients receiving laser surgery by Goor et al. [31] whereas Nunez Batalla et al. [30] and Dinapoli et al. [27] reported better emotional scores in patients receiving radiotherapy. Sjögren et al. [29] reported no difference. Better functional scores were reported by Nunez Batalla et al. [30] in patients receiving radiotherapy while Dinapoli et al. [27], Sjögren et al. [29] and Goor et al. [31] found no difference between the two groups.

\section{Quality of Life}

The quality of life was assessed in 2 studies [28, 31]. Goor et al. [31] used the COOP/Wonca chart and found no significant difference between patients receiving laser surgery versus radiotherapy. Patients receiving radiotherapy seemed to do be better in physical fitness and social activities but poorer in mental well-being and daily activities. The differences, however, were not statistically significant. Oridate et al. [28] used Voice-Related Quality of Life and also failed to find significant difference between the two treatment modalities.

\section{Treatment Cost}

Two studies [31,33] described the costs. Both revealed significantly lower total cost for laser surgery. None of the 2 studies assessed loss of income during treatment. In this respect, laser surgery is probably more economical as the treatment typically requires $<2$ days hospital stay whereas radiotherapy typically takes 5 or 6 weeks.

\section{Discussion}

Strong and Jako [38] began to use carbon dioxide laser to treat malignant lesions of the larynx in 1972. In the following decades, minimal tissue resection has been in- 
Table 2. Characteristics of the studies included in the meta-analysis

\begin{tabular}{|c|c|c|c|c|c|c|c|c|}
\hline Study ID & Design & Groups & $\begin{array}{l}\text { Sample } \\
\text { size }\end{array}$ & $\begin{array}{l}\text { Stage } \\
\text { included }\end{array}$ & $\begin{array}{l}\text { Mean or me- } \\
\text { dian age, years }\end{array}$ & $\begin{array}{l}\text { Radiation dose/ } \\
\text { number of fractions }\end{array}$ & $\begin{array}{l}\text { Length of } \\
\text { follow-up, months }\end{array}$ & Outcomes \\
\hline Dinapoli et al. [27] & $\mathrm{R}$ & $\begin{array}{l}\text { LS } \\
\text { RT }\end{array}$ & $\begin{array}{l}33 \\
49\end{array}$ & T1a, T1b & $\begin{array}{l}63 \\
64.5\end{array}$ & $\begin{array}{l}70 \mathrm{~Gy} / 35 ; 70.2 \mathrm{~Gy} / 39 ; \\
69.6 \mathrm{~Gy} / 58\end{array}$ & $\begin{array}{l}\text { less than } 180 \\
\text { less than } 96\end{array}$ & VHI \\
\hline Mahler et al. [35] & $\mathrm{P}$ & $\begin{array}{l}\text { LS } \\
\text { RT }\end{array}$ & $\begin{array}{l}188 \\
163\end{array}$ & T1a & $\begin{array}{l}67 \\
66\end{array}$ & $66-70 \mathrm{~Gy} / 30-35$ & 29 (minimum) & $\mathrm{LC}$ \\
\hline Oridate et al. [28] & $\mathrm{R}$ & $\begin{array}{l}\text { LS } \\
\text { RT }\end{array}$ & $\begin{array}{l}10 \\
43\end{array}$ & T1a, T1b & $\begin{array}{l}79 \\
71\end{array}$ & $65 \mathrm{~Gy}$ & $\begin{array}{l}24(\text { median }) \\
6(\text { median })\end{array}$ & VHI; QOL \\
\hline Schrijvers et al. [37] & $\mathrm{R}$ & $\begin{array}{l}\text { LS } \\
\text { RT }\end{array}$ & $\begin{array}{l}49 \\
51\end{array}$ & T1a & $\begin{array}{l}64 \\
67\end{array}$ & $60-70 \mathrm{~Gy} / 33$ & 60 (minimum) & $\mathrm{LC}$ \\
\hline Sjögren et al. [29] & $\mathrm{R}$ & $\begin{array}{l}\text { LS } \\
\text { RT }\end{array}$ & $\begin{array}{l}18 \\
16\end{array}$ & T1a & $\begin{array}{l}67 \\
69\end{array}$ & NR & $\begin{array}{l}45 \text { (mean) } \\
60 \text { (mean) }\end{array}$ & VHI \\
\hline $\begin{array}{l}\text { Nunez Batalla } \\
\text { et al. [30] }\end{array}$ & $\mathrm{R}$ & $\begin{array}{l}\text { LS } \\
\text { RT }\end{array}$ & $\begin{array}{l}19 \\
18\end{array}$ & $\begin{array}{l}\text { T1a } \\
\text { T1a, T1b }\end{array}$ & $\begin{array}{l}64 \\
67\end{array}$ & $6,525 \mathrm{cGy} / 29$ & $\begin{array}{l}30 \text { (mean) } \\
43 \text { (mean) }\end{array}$ & VHI \\
\hline Goor et al. [31] & $\mathrm{R}$ & $\begin{array}{l}\text { LS } \\
\text { RT }\end{array}$ & $\begin{array}{l}54 \\
31\end{array}$ & $\begin{array}{l}\text { T1a } \\
\text { T1a }\end{array}$ & $\begin{array}{l}64.7 \\
63.8\end{array}$ & $60 \mathrm{~Gy} / 24$ & $\begin{array}{l}22.5 \text { (mean) } \\
23 \text { (mean) }\end{array}$ & $\begin{array}{l}\text { LC; VHI; } \\
\text { QOL; Cost }\end{array}$ \\
\hline Peeters et al. [36] & $\mathrm{R}$ & $\begin{array}{l}\text { LS } \\
\text { RT }\end{array}$ & $\begin{array}{l}56 \\
46\end{array}$ & $\begin{array}{l}\text { T1a } \\
\text { T1a }\end{array}$ & $\begin{array}{l}66 \\
64\end{array}$ & $50-70 \mathrm{~Gy} / 20-35$ & 24 (minimum) & VHI \\
\hline Stoeckli et al. [32] & $\mathrm{R}$ & $\begin{array}{l}\text { LS } \\
\text { RT }\end{array}$ & $\begin{array}{l}65 \\
75\end{array}$ & $\mathrm{~T} 1, \mathrm{~T} 2$ & 63 & 70.2 Gy/39; 68 Gy/34 & $\begin{array}{l}60 \text { (mean) } \\
70(\text { mean })\end{array}$ & $\mathrm{LC}$ \\
\hline Brandenburg [33] & $\mathrm{R}$ & $\begin{array}{l}\text { LS } \\
\text { RT }\end{array}$ & $\begin{array}{l}30 \\
44\end{array}$ & T1a, T1b & $\begin{array}{l}64.5 \\
63.2\end{array}$ & 65-70 Gy & 64.5 (median) & Cost \\
\hline Epstein et al. [34] & $\mathrm{R}$ & $\begin{array}{l}\text { LS } \\
\text { RT }\end{array}$ & 17 & $\begin{array}{l}\text { T1a } \\
\text { T1a, T1b }\end{array}$ & 62 & $\begin{array}{l}66 \mathrm{~Gy} / 33 ; 64-70 \\
\mathrm{~Gy} / 35-36 ; 68 \mathrm{~Gy} / 34 \\
66-70 \mathrm{~Gy} / 35-37\end{array}$ & $\begin{array}{l}31 \text { (median) } \\
59 \text { (median) }\end{array}$ & $\mathrm{LC}$ \\
\hline
\end{tabular}

$\mathrm{P}$ = Prospective; $\mathrm{R}$ = retrospective; $\mathrm{LS}=$ laser surgery; $\mathrm{RT}=$ radiation therapy; $\mathrm{LC}=$ local control; VHI = voice handicap index; $\mathrm{QOL}=$ quality of life; $\mathrm{NR}=$ not reported.

creasingly accepted in clinical practice $[39,40]$. Such a change of attitude led to an increase in the popularity of laser surgery as the primary management for early glottic cancer [41].

The most commonly used types of treatment for early glottic cancer are radiotherapy and $\mathrm{CO}_{2}$ laser surgery [42]. The choice seems to vary significantly across countries. Radiotherapy is preferred in northern Europe whereas patients are more likely to be treated with surgery in the United States and southern Europe [18]. A number of original studies comparing the oncologic and functional outcomes, quality of life and costs of laser surgery and/or radiotherapy in the treatment of early-stage carcinoma were excluded from our meta-analysis because they did not meet the inclusion criteria. Our analy- sis demonstrated a similar cure rate for radiotherapy $[7$, $10,33,43]$ and laser surgery $[7,10,33,44-46]$, at $66-95 \%$ and $76-96 \%$, respectively. The results with regard to voice preservation are inconclusive. Five studies [10, 20, 25, 47, 48] reported no significant difference between the two treatments. Four studies reported [24, 34, 49] better voice quality after radiotherapy. Very few studies concluded that voice quality was better after laser surgery. The costs for Tla glottic cancer are substantially greater in patients treated with radiotherapy than in patients treated with laser surgery $[7,33,41,50]$. In all, both treatments achieve high and comparable cure rates. However, there remains controversy over voice quality, quality of life, risk of complications and cost. 


\begin{tabular}{|c|c|c|c|c|c|c|c|}
\hline \multirow{2}{*}{$\begin{array}{l}\text { Study } \\
\text { or subgroup }\end{array}$} & \multicolumn{2}{|c|}{ Laser surgery } & \multicolumn{3}{|c|}{ Radiotherapy } & \multirow{2}{*}{$\begin{array}{l}\text { Risk ratio } \\
\mathrm{M}-\mathrm{H} \text {, fixed }(95 \% \mathrm{Cl})\end{array}$} & \multirow{2}{*}{$\begin{array}{l}\text { Risk ratio } \\
\mathrm{M}-\mathrm{H} \text {, fixed }(95 \% \mathrm{Cl})\end{array}$} \\
\hline & events & total & events & total & weight, \% & & \\
\hline \multicolumn{8}{|c|}{ 5.1.1 2-year local control } \\
\hline Goor et al. [31] & 3 & 54 & 3 & 31 & 19.5 & $0.57(0.12,2.67)$ & \\
\hline Stoeckli et al. [32] & 8 & 65 & 17 & 75 & 80.5 & $0.54(0.25,1.17)$ & \\
\hline Subtotal $(95 \% \mathrm{CI})$ & & 119 & & 106 & 100.0 & $0.55(0.28,1.09)$ & \\
\hline Total events & 11 & & 20 & & & & \\
\hline \multirow{2}{*}{\multicolumn{8}{|c|}{$\begin{array}{l}\text { Heterogeneity: } \chi^{2}=0.00, \text { d.f. }=1(p=0.95), I^{2}=0 \% \\
\text { Test for overall effect: } Z=1.70(p=0.09)\end{array}$}} \\
\hline & & & & & & & \\
\hline \multicolumn{8}{|c|}{ 5.1.2 3-year local control } \\
\hline Epstein et al. [34] & 4 & 17 & 8 & 60 & 15.5 & $1.76(0.60,5.16)$ & $\rightarrow$ \\
\hline Mahler et al. [35] & 14 & 188 & 18 & 163 & 84.5 & $0.67(0.35,1.31)$ & \\
\hline Subtotal (95\% CI) & & 205 & & 223 & 100.0 & $0.84(0.48,1.47)$ & \\
\hline Total events & 18 & & 26 & & & & \\
\hline \multirow{2}{*}{\multicolumn{8}{|c|}{$\begin{array}{l}\text { Heterogeneity: } \chi^{2}=2.25, \text { d.f. }=1(p=0.13), I^{2}=56 \% \\
\text { Test for overall effect: } Z=0.60(p=0.55)\end{array}$}} \\
\hline & & & & & & & \\
\hline \multicolumn{8}{|c|}{ 5.1.3 5-year local control } \\
\hline Epstein et al. [34] & 4 & 17 & 9 & 60 & 11.9 & $1.57(0.55,4.47)$ &. \\
\hline Schrijvers et al. [37] & 14 & 49 & 14 & 51 & 41.0 & $1.04(0.56,1.95)$ & 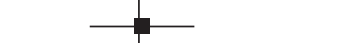 \\
\hline Stoeckli et al. [32] & 9 & 65 & 17 & 75 & 47.2 & $0.61(0.29,1.28)$ & - \\
\hline \multirow{2}{*}{$\begin{array}{l}\text { Subtotal }(\mathbf{9 5 \%} \mathrm{CI}) \\
\text { Total events }\end{array}$} & & 131 & & 186 & 100.0 & $0.90(0.59,1.39)$ & \\
\hline & 27 & & 40 & & & & \\
\hline \multicolumn{8}{|c|}{$\begin{array}{l}\text { Heterogeneity: } \chi^{2}=2.35, \text { d.f. }=2(p=0.31), I^{2}=15 \% \\
\text { Test for overall effect: } Z=0.48(p=0.63)\end{array}$} \\
\hline & & & & & & & $\begin{array}{llll}2 & 0.5 & 1 & 2\end{array}$ \\
\hline & & & & & & Favors ex & erimental Favors control \\
\hline
\end{tabular}

Fig. 1. Comparison of local control rate of laser surgery versus radiotherapy for early glottic cancer.

Our meta-analysis failed to show a significant difference between $\mathrm{CO}_{2}$ laser surgery and radiotherapy in the rate of local control at 2, 3 and 5 years (fig. 1). However, there was significant heterogeneity in patient selection (T1a vs. T1-T2, T1 vs. T1a, T1 vs. T1a vs. T1-2). Also, there is no significant difference between $\mathrm{CO}_{2}$ laser surgery and radiotherapy in quality of life. Total cost of radiotherapy is significantly higher than that of $\mathrm{CO}_{2}$ laser surgery.

The current study has several limitations. None of the included studies were randomized controlled clinical trials. Only one study was prospective in design; the remaining studies were retrospective and had a relatively small sample size. Moreover, there was significant heterogeneity in tumor stage, dosing and schedule of radiotherapy, duration prior to voice assessment and the follow-up. Expanding the search to languages beyond English and Chinese might have identified more goodquality studies.

\section{Conclusion}

Our analysis reveals a lack of well-designed prospective studies. Our analysis of the limited evidence failed to identify any difference in local control in patients with early glottic cancer receiving laser surgery versus radiotherapy. The effects on voice preservation require further study. Treatment cost is lower with laser surgery. Based on these findings, we believe that laser surgery is a more attractive option for patients with early glottic cancer based on economic considerations.

\section{Disclosure Statement}

We do not have any potential financial conflicts of interest or otherwise. 


\section{References}

${ }_{1}$ Ferlay J, Shin H, Bray F, Forman D, Mathers C, Parkin D: Estimates of worldwide burden of cancer in 2008: GLOBOCAN 2008. Int J Cancer 2010;127:2893-2917.

$\checkmark 2$ Wight R, Paleri V, Arullendran P: Current theories for the development of nonsmoking and nondrinking laryngeal carcinoma. Curr Opin Otolaryngol Head Neck Surg 2003;11: 73-77.

\3 Hoffman HT, Porter K, Karnell LH, Cooper JS, Weber RS, Langer CJ, Ang KK, Gay G, Stewart A, Robinson RA: Laryngeal cancer in the United States: changes in demographics, patterns of care, and survival. Laryngoscope 2006;116:1-13.

4 Woodhouse RJ, Quivey JM, Fu KK, Sien PS, Dedo HH, Phillips TL: Treatment of carcinoma of the vocal cord. A review of 20 years' experience. Laryngoscope 1981;91:11551162.

5 Ton-Van J, Lefebvre JL, Stern JC, Buisset E, Coche-Dequeant B, Vankemmel B: Comparison of surgery and radiotherapy in $\mathrm{T} 1$ and T2 glottic carcinomas. Am J Surg 1991;162: 337-340.

6 Mittal BRD, Marks JE, Perez CA: Role of radiation in the management of early vocal cord carcinoma. Int J Radiat Oncol Biol Phys 1983;9:997-1002.

7 Cragle SP, Brandenburg JH: Laser cordectomy or radiotherapy: cure rates, communication, and cost. Otolaryngol Head Neck Surg 1993;108:648-654.

8 Davis RK, Kelly SM, Parkin JL, Stevens MH, Johnson LP: Selective management of early glottic cancer. Laryngoscope 1990;100: 1306-1309.

9 Pellitteri PK, Kennedy TL, Vrabec DP, Beiler D, Hellstrom M: Radiotherapy. The mainstay in the treatment of early glottic carcinoma. Arch Otolaryngol Head Neck Surg 1991;117:297-301.

- 10 Rosier JF, Grégoire V, Counoy H, OctavePrignot M, Rombaut $\mathrm{P}$, Scalliet $\mathrm{P}$, Vanderlinden F, Hamoir M: Comparison of external radiotherapy, laser microsurgery and partial laryngectomy for the treatment of T1N0M0 glottic carcinomas: a retrospective evaluation. Radiother Oncol 1998;48:175-183.

11 Radiotherapy versus open surgery versus endolaryngeal surgery (with or without laser) for early laryngeal squamous cell cancer. Cochrane Database Syst Rev 2002:CD002027.

-12 Higgins KM, Shah MD, Ogaick MJ, Enepekides D: Treatment of early-stage glottic cancer: meta-analysis comparison of laser excision versus radiotherapy. J Otolaryngol Head Neck Surg 2009;38:603-612.

13 Siwek J, Gourlay ML, Slawson DC, Shaughnessy AF: How to write an evidence-based clinical review article. Am Fam Physician 2002;65:251-258.
14 Phillips TJ, Sader C, Brown T, Bullock M, Wilke D, Trites JR, Hart R, Murphy M, Taylor SM: Transoral laser microsurgery versus radiation therapy for early glottic cancer in Canada: cost analysis. J Otolaryngol Head Neck Surg 2009;38:619-623.

15 Mlynarek A, Kost K, Gesser R: Radiotherapy versus surgery for early T1-T2 glottic carcinoma. J Otolaryngol 2006;35:413-419.

16 Loughran S, Calder N, MacGregor FB, Carding P, MacKenzie K: Quality of life and voice following endoscopic resection or radiotherapy for early glottic cancer. Clin Otolaryngol 2005;30:42-47.

17 Krengli M, Policarpo M, Manfredda I, Aluffi P, Gambaro G, Panella M, Pia F: Voice quality after treatment for Tla glottic carcino$\mathrm{ma}$ - radiotherapy versus laser cordectomy. Acta Oncol 2004;43:284-289.

18 Jones AS, Fish B, Fenton JE, Husband DJ: The treatment of early laryngeal cancers (T1-T2 N0): Surgery or irradiation? Head Neck 2004;26:127-135.

19 Tamura E, Kitahara S, Ogura M, Kohno N: Voice quality after laser surgery or radiotherapy for T1a glottic carcinoma. Laryngoscope 2003;113:910-914.

20 Wedman J, Heimdal JH, Elstad I, Olofsson J: Voice results in patients with Tla glottic cancer treated by radiotherapy or endoscopic measures. Eur Arch Otorhinolaryngol 2002 259:547-550.

21 Spector JG, Sessions DG, Chao KS, Haughey BH, Hanson JM, Simpson JR, Perez CA: Stage I (T1 N0 M0) squamous cell carcinoma of the laryngeal glottis: therapeutic results and voice preservation. Head Neck 1999;21: 707-717.

22 Grégoire V, Hamoir M, Rosier JF, Counoy H, Eeckhoudt L, Neymark N, Scalliet P: Costminimization analysis of treatment options for T1N0 glottic squamous cell carcinoma: comparison between external radiotherapy, laser microsurgery and partial laryngectomy. Radiother Oncol 1999;53:1-13.

23 Foote RL, Buskirk SJ, Grado GL, Bonner JA: Has radiotherapy become too expensive to be considered a treatment option for early glottic cancer? Head Neck 1997;19:692-700.

24 Rydell R, Schalen L, Fex S, Elner A: Voice evaluation before and after laser excision vs radiotherapy of T1a glottic carcinoma. Acta Otolaryngol 1995;115:560-565.

-25 McGuirt WF, Blalock D, Koufman JA, Feehs RS, Hilliard AJ, Greven K, Randall M: Comparative voice results after laser resection or irradiation of T1 vocal cord carcinoma. Arch Otolaryngol Head Neck Surg 1994;120:951955.

26 Chen WC, Chen LH, Leung WM, Tang SG, Tsai MH, Liao CT, See LC: Comparison of radiotherapy and surgical results of early stage glottic cancer: a retrospective analysis. J Formos Med Assoc 1993;92:1076-1083.
27 Dinapoli N, Parrilla C, Galli J, Autorino R, Micciche F, Bussu F, Balducci M, D’Alatri L, Marchese R, Rigante M, Di Lella G, Liberati L, Almadori G, Paludetti G, Valentini V: Multidisciplinary approach in the treatment of T1 glottic cancer. The role of patient preference in a homogenous patient population. Strahlenther Onkol 2010;186:607-613.

$\checkmark 28$ Oridate N, Homma A, Suzuki S, Nakamaru Y, Suzuki F, Hatakeyama H, Taki S, Sakashita T, Nishizawa N, Furuta Y, Fukuda S: Voice-related quality of life after treatment of laryngeal cancer. Arch Otolaryngol Head Neck Surg 2009;135:363-368.

29 Sjögren EV, van Rossum MA, Langeveld TP, Voerman MS, van de Kamp VA, Friebel MO, Wolterbeek R, Baatenburg de Jong RJ: Voice outcome in Tla midcord glottic carcinoma: laser surgery vs. radiotherapy. Arch Otolaryngol Head Neck Surg 2008;134:965-972.

30 Nunez Batalla F, Caminero Cueva MJ, Senaris Gonzalez B, Llorente Pendas JL, Gorriz Gil C, Lopez Llames A, Alonso Pantiga R, Suarez Nieto C: Voice quality after endoscopic laser surgery and radiotherapy for early glottic cancer: OBJECTIVE measurements emphasizing the voice handicap index. Eur Arch Otorhinolaryngol 2008;265: 543-548.

31 Goor KM, Peeters AJ, Mahieu HF, Langendijk JA, Leemans CR, Verdonck-de Leeuw IM, van Agthoven M: Cordectomy by $\mathrm{CO}_{2}$ laser or radiotherapy for small Tla glottic carcinomas: costs, local control, survival, quality of life, and voice quality. Head Neck 2007;29:128-136.

32 Stoeckli SJ, Schnieper I, Huguenin P, Schmid S: Early glottic carcinoma: treatment according patient's preference? Head Neck 2003;25: 1051-1056.

33 Brandenburg JH: Laser cordotomy versus radiotherapy: an objective cost analysis. Ann Otol Rhinol Laryngol 2001;110:312-318.

$>34$ Epstein BE, Lee DJ, Kashima H, Johns ME: Stage T1 glottic carcinoma: results of radiation therapy or laser excision. Radiology 1990; 175:567-570.

35 Mahler V, Boysen M, Brondbo K: Radiotherapy or $\mathrm{CO}_{2}$ laser surgery as treatment of $\mathrm{T}_{1 \mathrm{a}}$ glottic carcinoma? Eur Arch Otorhinolaryngol 2010;267:743-750.

-36 Peeters AJ, van Gogh CD, Goor KM, Verdonck-de Leeuw IM, Langendijk JA, Mahieu HF: Health status and voice outcome after treatment for T1a glottic carcinoma. Eur Arch Otorhinolaryngol 2004;261:534-540.

37 Schrijvers ML, van Riel EL, Langendijk JA, Dikkers FG, Schuuring E, van der Wal JE, van der Laan BF: Higher laryngeal preservation rate after $\mathrm{CO}_{2}$ laser surgery compared with radiotherapy in T1a glottic laryngeal carcinoma. Head Neck 2009;31:759-764. 
-38 Strong MS, Jako GJ: Laser surgery in the larynx. Early clinical experience with continuous $\mathrm{CO}_{2}$ laser. Ann Otol Rhinol Laryngol 1972;81:791-798.

-39 Steiner W: Results of curative laser microsurgery of laryngeal carcinomas. Am J Otolaryngol 1993;14:116-121.

40 Pearson BW, Salassa JR: Transoral laser microresection for cancer of the larynx involving the anterior commissure. Laryngoscope 2003;113:1104-1112.

-41 Shah JP, Karnell LH, Hoffman HT, Ariyan S, Brown GS, Fee WE, Glass AG, Goepfert H, Ossoff RH, Fremgen A: Patterns of care for cancer of the larynx in the United States. Arch Otolaryngol Head Neck Surg 1997;123: 475-483.
42 Mendenhall WM, Werning JW, Hinerman RW, Amdur RJ, Villaret DB: Management of T1-T2 glottic carcinomas. Cancer 2004;100: 1786-1792.

43 Kaiser TN, Sessions DG, Harvey JE: Natural history of treated T1N0 squamous carcinoma of the glottis. Ann Otol Rhinol Laryngol 1989;98:217-219.

44 Thomas JV, Olsen KD, Neel HB 3rd, DeSanto LW, Suman VJ: Recurrences after endoscopic management of early (T1) glottic carcinoma. Laryngoscope 1994;104:1099-1104.

45 Myers EN, Wagner RL, Johnson JT: Microlaryngoscopic surgery for T1 glottic lesions: a cost-effective option. Ann Otol Rhinol Laryngol 1994;103:28-30.

46 Koufman JA: The endoscopic management of early squamous carcinoma of the vocal cord with the carbon dioxide surgical laser: clinical experience and a proposed subclassification. Otolaryngol Head Neck Surg 1986;95:531-537.
47 Hirano M, Hirade Y, Kawasaki H: Vocal function following carbon dioxide laser surgery for glottic carcinoma. Ann Otol Rhinol Laryngol 1985;94:232-235.

48 Delsupehe KG, Zink I, Lejaegere M, Bastian RW: Voice quality after narrow-margin laser cordectomy compared with laryngeal irradiation. Otolaryngol Head Neck Surg 1999; 121:528-533.

49 Elner A, Fex S: Carbon dioxide laser as primary treatment of glottic T1s and T1a tumours. Acta Otolaryngol Suppl 1988;449: 135-139.

50 Smith JC, Johnson JT, Cognetti DM, Landsittel DP, Gooding WE, Cano ER, Myers EN: Quality of life, functional outcome, and costs of early glottic cancer. Laryngoscope 2003; 113:68-76. 